\title{
コモンズ構築と利用のための知識表現
}

\section{Knowledge representation to build and utilize commons}

\author{
クレイネス・スティーブン \\ Steven KRAINES
}

東京大学総括プロジェクト機構

Division of Project Coordination, The University of Tokyo

于277-8563 千葉県柏市柏の葉5-1-5

E-mail: sk@scint.dpc.u-tokyo.ac.jp

\section{1. 情報爆発と新たな可能性}

今の社会問題は, 間違いなく大規模かつ 複雑で，緊急に解決すべきものになってい るのですが，その一方で，著しい学術知識 の蓄積があります，仮に，科学知識コモン ズが成立していれば，そこに，社会問題を 解決するための多くの答えがあるはずだと 期待しています。また，科学知識コモンズ を構築するために，本質的に人は協力した い，非常に協力したいのにうまく協力でき ていない，要するに何らかの障壁がそこに はあるのではないかと思います。その一つ が，科学知識コモンズが成立した時にそれ をうまく活用するための準備が出来ていな い，そのためにコモンズの有効性や必要性 を広く確信させるに至っていないというこ とではないかと私は考えています。

現在，情報の爆発が問題としてしばしば 取り上げられています。しかし，よく考え てみると，この情報爆発は，本来問題では ない．より多くの情報があること，それ自 体はいいことです。ところが問題だという。 どうしてでしょうか? 要するに, 情報爆発
が, 機会の爆発になればいいのですけれど, なかなかなっていない，なんとかして，情 報爆発を機会爆発に変換することが私の研 究の目的です.

他の講演でも議論されているように，科 学知識コモンズを構築する障害がいくつか あります。一つは，法的なライセンシング やコピーライトに関する課題があります。 もう一つはビジネスモデルなどの経済的な 課題です。これらがが解決すれば，確かに フリーのコモンズは成立するかも知れませ ん.しかし，フリーのコモンズだけでは， 今ですら, Google で何を検索すればいいか わからなくなっているのに，情報がオープ ンになって，コモンズ上に蓄積される情報 量が増えると，さらに情報爆発に伴う課題 が増えるのではないかという心配がありま す.

\section{Fluent なコモンズに向けて}

現在でも, 適切な情報を探すのは難しい. また，検索してもわかっていることしか見 
つからないといったことがあります。それ は結局, 法的, 経済的にコモンズを作るこ と，また，法的・経済的にアクセシビリテ イを確保すること，それも非常に重要なの ですが，意味的なアクセシビリティも担保 しなければならないということではないか と考えています。そのために，Free である ことに加えて， Fluent なコモンズを作らな くてはいけないと考えています。

Fluent なコモンズとはなんなのか，もう 少し具体的にお話したいと思います。人間 は知識を処理する能力がある, しかし，や はり限界があります。たぶん勤勉で有能な 研究者でもせいぜい年間 100 本くらいの論 文しか，きちんとと把握する時間がないの ではないでしょうか. 特に企業にいる方々 はそんなことはとてもやっていられない.

大昔であれば自分の研究に関連する論文数 が，読める量と同じくらい，あるいはそれ 以下であったために，関連する論文を全て 読み切れたのでしょう。しかし，今では， 論文の数が増えている一方, 人間の能力と いうのはなかなか向上しないので, 当然全 ては把握できない，今の状況を例えていう と, 情報の海の中で, 自分の関連する知識 や良い論文がひっかかるよう，運を天に任 せている状態だといえるかもしれません. おそらく, 今の研究者, 特に統合的な研究 課題に従事している人たちにとって，毎年 出版される, 自分の研究に関連する論文の 数は, 簡単に 1 万通に届くと思います.

この本来把握しなければならない 1 万通 を，たった 100 通だけしか読めない人がど のように把握すればよいのかというと，基 本的に 2 つの方法があるのではないかと考 えています。1つは，コンピュータに任せ てしまう。例えば，テキストマイニング技
術を用いて, 1 万通を 100 分の 1 に圧縮し て，100 通くらいの分量に減らすといった ことです。もう 1 つは，正確なマッチング によって，1 万通の中で本当に読むべき 100 通はどれかを正確に探し出すことです.

それでは，1つ目の方法はじこまで期待 できるでしょうか。これまでコンピュータ でじこまで可能か, 多くの研究がなされて きました. 自動知識マイニング, 自動要約, 知識発見, in silico と，それぞれの研究者が 作ったいろいろな言葉がありますが，大き くいうと 2 種類の方法が良く用いられてい ます。1つは，手動あるいは自動で作った テンプレートやルールを使って，個々の論 文から知見を抽出することです。もう 1 つ は，数多くの論文を見て，その中のキーワ 一ドか何か，それらの相互関係を使って， 知識を抽出することです.

いずれにしても，コンピュータを用いて 分析するためには, コンピュータがコンピ ユータの処理できる形に，人間の言葉を翻 訳しなければいけないのです。しかし，そ れは矛盾しているのではないでしょうか. 人間が人間のために書いたコンピュータが もともと読めない文章を，どうしてコンピ ユータが処理できるのでしょうか.これに ついては，いろんな人がいろいろなことを 言っています。例えば Erhardt さんが，もう 何年も前に”NLU is an AI-complete problem” という言い方をしました。要は, NLU(Natural Language Understanding)は AI でも解決できない問題だということです. 根本的な問題は, 自然言語の曖昧性です. そのため, コンピュータにとって自然言語 を理解して処理しようという試み は, ”Garbage in, Garbage out”であるといえ るでしょう。 
そもそも自然言語からの自動抽出はそれ ができたとしても，はたして良いことと言 えるのでしょうか? 研究者は, 論文を書く 時, 非常に苦労して, コンピュータが処理 するためのものではなくて，人間が読むた めのものを作ります。そのためにいろんな ストーリーや論理構造, 文法を使います。 それをコンピュータに任せて抽出して, 抽 出した結果しか, 人が見ないとすると, 何 かがおかしい，それをおかしいと言ってい る人が実は既にいまして，学術論文を書く のをやめて, 別な形, 例えば, すべてデー タベースのデータとして出版してはどうか ということを言っています。でもそれはち よっと違うと思います。何百年の経験によ ると, やっぱり未だに学術論文は最も有効 な科学技術に関する専門知識の伝達媒体で あるのです。それは既に指摘したように， 学術論文はストーリーであるし, 論理構造 であるからです. ”The role of paper is to convince the reader.”つまり, 論文とデータベ ースでは役割が違うのです.

もう少し詳しく考えたいのですが, 科学 技術の専門家は，何のために論文を書くの でしょうか?よく言われるように，起源は 文通ですよね. Physical Review Letters とか, Communications of ACM といった著名な学 術雑誌の名称にも表れているように，もと もとは例えば，アイザック・ニュートンが オリジナルなアイディアを着想すると, そ れを手紙に書いて, 友人みんな知らせて, 友人は自分の考えとマッチングして返信す る, それでみんなで知識を共有して, 研究 を進めていくのです，送信者と受信者の間 に広大な海があったとしても，信頼性の高 い郵便局に任せて, 本当に読むべき, 知ら せるべき相手の元へ届けて蒷っているので
寸.

残念ながら現在では状況は違います，私 のような若い研究者だけの悩みかも知れま せんが，今，論文を書くとこれは手紙では なくて, 瓶に詰められたメッセージなので す。一生懸命書いた論文を瓶に詰めて, コ ルクをかけて海に捨てて, 運を天に任せて, または Google Scholar に任せて, 適切な人 にメッセージが届くのを待っています。こ れは情報量の増加とともに, グローバル化, 知識経済課とともに, 社会が必要とする専 門家の数が増えて, 誰が本来届けるべき相 手なのか私が把握しきれないからでもあり ます。確かに論文を探している人は一生懸 命探しています.いろんな技術を使ったり, Google を使ったり, Web of Science を使っ たりしています。しかし，それはスピード ボートで，あちこち瓶を探しているような もので，それでもなかなかどの瓶を拾えば いいか判断するのが難しい.

今の問題は needs と seeds のマッチングで はないかと思います。昔は，フランシス・ ベーコンが言ったように，「知は力なり」 でしたが，今のインターネットの時代，知 識を持っている人がパワーではなくて, 他 人の注目や時間を集められる人がパワーと なっています.また, 個人や社会にとって, 時間が希少資源になっていると思います。 現在のボトルネックは, 分野も違いもある と思いますが，情報が足りないということ ではなくて，溢れている情報の中からどれ とどれの情報を使えばいいか，限られた時 間の中で，良いマッチ・メーキングが出来 るかどうかだと思います。高度な情報検索 技術を用いたサーチエンジンが本来それを 可能にしてくれるはずですが，理想のサー チエンジンは彥で言うと, ”The diamond in 
the rough”，それを探したいですよね.玉石 混交の中からダイヤの原石が欲しい. みん なが当然知っている情報ではなくて， diamond in the rough, だけれども, やっぱり pagerank や citationの数を手掛かりに探すと, The rich get richer, 結局, 知られているもの しか知られないのです。

本当に必要な情報との意味的なマッチン グを可能とするためには，ただ統計学的な pagerank だけを使うのは不十分です.さら には, matching の precision をあげる, 要す るに正しい答えのみを探すだけではなくて, recall をあげる, つまり, 通常の検索が落と してしまうような答えまでちやんと探すよ うな検索が必要です。

\section{3.科学知識の伝達とコンピュータ による理解}

それではどうすれば良いのか?ここで科 学知識の伝達とコンピュータによる理解と いうことを考えてみたいと思います。いう までもなく, 科学的な知識は社会的な課題 の解決において重要な役割を果たしていま す。しかし，それを以下に伝達するか，特 に情報の広範な伝達に Web が必須となっ ている現代において，以下に伝達するかと いうことは非常に大きな課題です.

ある人が社会問題の解決に繋がるような アイディアを何か持っていて，それに関す る文章を書いたとします。それが適切な人 に届けば, 問題の解決に何らかの形で貢献 するでしょうが，今の状況だと必ずしも届 くとは限らない，役に立つ知識を探してい る人は, 探すべき量が多いし, 誰に聞けば いいかわからないから，コンピュータに任 せてしまう。ですので, コンピュータがち やんと機能しないと駄目だし, コンピュー
タにとって理解可能な知識の記述が必要で す. 検索側は当然, コンピューターに理解 可能な形で検索を行います. クエリを作っ て，人によっては, ブーリアン検索までや ったりするのですけれど, 知識の側はどう なっているのでしょうか? 今は, 情報抽出 や自然言語処理を使って, コンピュータが コンテンツを, 人間が理解可能な領域から コンピュータが理解可能な領域へと無理や り持っていこうとしているのです.

現在の検索システムは，ものすごく性能 の良い受信機のみを使っているといえるか と思います。その受信機にいくつかキーワ 一ドを登録すると，その受信機が一生懸命 にレーザーを使ってアンテナにひっかかる ものがないか探して，当てはまるキーワー ドがあれば「これがいいかも知れない」と 言っているのです。しかし，マッチングの 精度を高めるためには，発信機を作らない といけません。その発信機は人の使うもの ではなくて，人が使っている受信機のため の装置という意味です。各論文が自分の持 つている知識の中身について, 受信機に分 かる形で発信する。 そうすれば，精度よく マッチングして，関連する論文が拾えるの ではないかと思います。

この発信機の持っている知識の記述は, コンピュータではなく人間が作るべきもの だと思います，そのために重要な課題は,

「人間がコンピュータの処理できる記述を 作るときに, どのような言語を使うべきか」 ということです。それでは，コンピュータ が理解可能な表現っていったい何なのでし ようか?

4.コンピュータが理解可能な表現 まずは理解, 英語で言うと to understand, 
ということを，よく考えなければならない と思います。様々な定義がありますが，科 学の理解にもつともふさわしい定義はこの ようなものかと思います。”To perceive and comprehend the nature and significance of” $屯$ しくは, "To grasp the significance, implications, or importance of”. 要するに, 科 学技術的な表現を理解するというのは, 統 計処理だけではないんです. ”asserted facts” から”implied facts”を推論したり, 表現した expression を事前にある mental models にマ ッピングしたりして，新たな意味合いを推 論したりするということです.

また，科学技術での fact は，ただ一つの概 念で表すことができるものではないのです. 本質は，概念同士の関係にあります，従っ て, コンピュータが理解可能な表現である ためには，概念同士の関係が表現できる知 識表現である必要性があるかと思います。

そこで, 我々が使っているのが, 記述論 理に基づいて，概念間の関係性を表現する 記述論理オントロジーです. 記述論理と言 うのは, first order predicate logic, 人間が比 較的に理解しやすいように修正した論理だ と私は考えています。 それは対象分野の概 念の関係も, 人間が共有する知識の対象物 の関係も十分に表現できるように作った理 論的な言語です. かつ, 現在のコンピュー タ・アルゴリズムによって計算できる言語 です，そのため，の記述論理に基づくオン トロジーを使うことで，人間はコンピュー タが意味的に処理できる記述を作成するこ とができます，そのプロトタイプとして， 私は記述論理オントロジーを直感的に簡便 に作成可能な Web システム, EKOSS (Engineering/Environmental Knowledge Ontology-based Semantic Search)システムを
作成しています。

EKOSS システムは, コンピュータが理解 可能な記述に基づいて記述論理の推論をし ようとする，インテリジェントな検索の実 現を目指しています。知識の探索者が, 知 識の提供者が意図した内容で，概念間の関 係を得られるように，さらにいうと，個々 の知識を組み合わせることで, 個々の提供 者が想定していた以上の知識を発見できる ようにしたいと思います，検索エンジンが 知識記述と, 検索条件の関係, さらに, 存 在する潜在的な理論関係も探し出せるよう になれば，検索の precision も recall も上が ると期待しています.

EKOSS システムを使って, JTS の失敗知 識データベースに格納されている事例を記 述して分析した例を使って，具体例を紹介 したいと思います。例えば，ある人，例え ば工事現場の主任が自分の担当の現場で, 特にその現場のような都市地域で, 事故が 起こらないようにどのようにチームをマネ ジメントすれば良いか, 過去の事故の事例 から学びたいと考えたとします。通常は, 幾つかのキーワード, 例えば, 工事現場, 建設, 土木, 組織といったものをクエリと して, Google か何かで検索すると思います. そうすると, 里地通信や臨海副都心や入学 試験など，およそ無関係なものが検索のラ ンキングの上位に現れてきてしまいます. また，仮に該当するページがヒットしたと しても，事故がマネジメントとどのように 関係しているのかすぐには把握できない. ところが, EKOSS システムを用いて, 各知 識に, 記述論理オントロジーを与え, それ を用いて検索すると, 溝の堀削作業中, コ ンクリートブロック塀が倒壊した事例がマ ッチングし，なおかつ，それが手順を無視 
した手抜きから生じたものであるというこ とまでもが瞬時に理解出来てしまいます. この概念間の関係性の把握ということ大変 重要であると考えています。現在のシステ ムではまだマッチングは完璧とはいえず, 違う事例もマッチングされることがありま すが，それでさえ，オントロジーを用いた 検索では，検索意図に対して，何らかの示 唆を与える場合が多いのです.

しかし，このような検索システムが有効 に機能するようになるには，まだまだ問題 があります。受信機と発信機の例えでいく と, 発信機を備えている知識の数が圧倒的 に足りないのです. そうすると, 検索シス テムとしては, 発信機を備えている知識の みを探していては，とても検索要求に耐え ることが出来ない，従って，発信機を取り 付けてくれる人の数を増やさないといけな い，そのためには 2 つ重要な条件がある かと思います。1つは受信機を使うシステ ムも発信機を取り付けるシステムも使いや すいこと，もう1つは，使ったらすぐ利便 性が見えることです.

ますは, Ease of use, 使いやすいためには, 直感的に記述論理オントロジーを作成，利 用可能な使えるツールが必要になってきま す。また, Instant gratification, すぐに利便 性がわかるようなものにするには，様々な アプリケーションが必要になってきます. 私は，このような人間の手でコンピュータ の理解可能な記述を作り, それを膨大な量 の知識に対し実装していくことが。今後ま すます必要になってくると考えています。

しかし, Ease of use といっても，やはり 単なるキーワード検索よりは個々の検索に 時間がかかります。しかし, Google 検索で は一回一回の検索はすぐにできるとはいっ
ても，ちやんとマッチングしたサイトに辿 り着くには，ブーリアンサーチとか一生懸 命考えて繰り返し行う必要がありますし, 繰り返したとしても, すぐに精度は saturate してしまう。そのの方, EKOSS システムで は classを選んだり, instance 名を入力した り，最初はやはり時間がかかってしまう。 でも property と instance を結んだり, 複数 のグラフを作ったりすることによってどん どんと精度を上げることが可能です。

また，知識を記述する側にも余計な時間 がかかります。自然言語に加えて, 機械可 読な言語で知識を用意するわけですから. よく指摘を受けるのですが，論文を書いて いる人は大変忙しくて，さらにややこしい 記述を作ったりすることは，これはもうと んでもないと.でもよくよく考えてみると， 研究者は，論文を作るために非常に時間を かけています。それこそ何十時間と，論文 を書くために研究をしている時間は何百日 かもしれない.しかし，その結果として出 来た論文は Nature とかみんなが必ず見るよ うなジャーナルだったらいいのですが，私 たちが書く論文の多くはどこに行っちやっ たかという感じです。キーワードをあちこ ち登録したり，自分の論文をあちこち宣伝 すればもう少し読まれるようになるかもし れない. しかし, やはりそれは限界がある。 自分の論文のオントロジを作るのに 1 時間 かかかったとしても，論文を書く 100 時間 に比べれば，それほど過大な負担とはなら ないと思いたいです。

次に, instant gratification ですが，明らか にキラーアプリケーションが必要です。私 たちは良く言うのですけれど，キラーアプ リケーションとして, 次の Facebook を作り たいのです. instant gratification とするには, 
community of practice が成り立たないとい けないのです。そのためには，すぐにわか る付加価值が必要で, なんとなく長期には メリットがありそうだとしても，なかなか それだけでは動かない。

それで，我々の行っている一つの試みが 自然言語生成です。記述論理オントロジー に基づいて作った semantic network があり ます。これは, 膨大な複雑なグラフで表現 されます。これはやっぱり人間には読めな い，人間はこういうものを読むのはやっぱ り辛い。でも，この内容はコンピュータが 理解できる．コンピュータが理解できるか ら，正確に自然言語に変換や翻訳ができま す。 日本語で表現する場合. 英語で表現す る場合, 中国語で表現する場合, 概念を才 ントロジーとして登録することで翻訳が出 来る.よくよく読むと, 当然, あまりきれ いな文章ではないのですが，正確な文章に なっているはずです。で, これがポイント です。コンピュータが意味をわかるから， 正確な表現になっているのです.

ここまでの話を堅苦しい表現でまとめる と, モノとモノの特定した関係が表現でき
る記述論理に基づく知識表現言語を用いて， 人間がコンピュータ理解可能な記述を作れ ば，その記述を用いて，コンピュータが知 識リソースの間の意味的なマッチをする際, そのマッチは現状より極めて正確かつ「面 白い」思わぬ関係を探し出せるものになる はずであるということです.コンピュータ が理解可能な semantic search が実現できれ ば，ルールや理論に基づいた，人工知能的 なインテリジェントなマッチングや推論が 可能ですし, 数多くの知識が記述論理オン トロジーで表現されれば，それをマイニン グすることで, 色々な知識の発見がうまれ てくると思います．Free なコモンズの実現 は非常に重要な課題ですし，重要であるに も関わらず未だに十分に実現できていませ ん.しかし，実現できていないからといっ て，コモンズの利用技術に手をつけないの ではなく, 今の段階から, Fluent なコモン ズを実現するための技術の開発に着手す心゙ きであるし，コモンズに登録される知識の 表現形式についても議論を始めるべきであ ると思います。 